\title{
PENGARUH FAKTOR FUNDAMENTAL PERUSAHAAN TERHADAP RETURN SAHAM
}

\author{
Egis Tubagus Purnama1) \\ Said Kelana Asnawi2) \\ Etty Puji Lestari3) \\ 1)PT. Lintas Kumala Abadi \\ 2)Institut Bisnis dan Informatika Kwik Kian Gie \\ 3)Universitas Terbuka \\ e-mail: egistubagus@gmail.com
}

\begin{abstract}
This research is conducted to analyze the influence of fundamental factor of company to stock return on coal mining sector which listed in Indonesia Stock Exchange in year 20142016. Fundamental factors are represented by CR, MP/TA, FA/TA, DER and ROA. The object of this research is the coal mining sector companies listed on the Indonesia Stock Exchange which submits the financial statements during the period 2014-2016. The sample of this research consists of 11 companies and 33 observations. Statistical methods used in this research is multiple regression analysis. The results of this research indicate that FA/TA and $R O A$ affect stock return on coal mining sector which listed in Indonesia Stock Exchange in year 2014-2016, while CR, MP/TA, and DER do not affect to stock return on coal mining sector which listed in Indonesia Stock Exchange in year 2014-2016.
\end{abstract}

Keywords: fundamental factor, current ratio, debt to equity ratio, return on assets, stock return

\begin{abstract}
ABSTRAK
Penelitian ini dilakukan untuk menganalisis pengaruh faktor fundamental perusahaan terhadap return saham pada sektor pertambangan batu bara yang terdaftar di Bursa Efek Indonesia pada tahun 2014-2016. Faktor fundamental di wakili oleh CR, MP/TA, FA/TA, DER dan ROA. Obyek penelitian ini adalah perusahaan yang termasuk di dalam sektor pertambangan batu bara yang terdaftar di Bursa Efek Indonesia yang menyampaikan laporan keuangan sepanjang periode tahun 2014-2016. Sampel penelitian ini terdiri dari 11 perusahaan dengan jumlah pengamatan sebanyak 33 pengamatan. Metode statistik yang di gunakan dalam penelitian ini adalah analisa regresi berganda. Hasil penelitian ini menunjukan bahwa FA/TA dan ROA memberikan pengaruh teradap return saham pada sektor pertambangan batu bara yang terdaftar di Bursa Efek Indonesia pada tahun 20142016, sedangkan CR, MP/TA dan DER tidak memberikan pengaruh terhadap return saham pada sektor pertambangan batu bara yang terdaftar di Bursa Efek Indonesia pada tahun 2014-2016.
\end{abstract}

Kata kunci: Faktor fundamental, current ratio, debt to equity ratio, return on assets, return saham 
Untuk meningkatkan nilai kekayaannya dan melindungi penurunan nilai dari inflasi menyebabkan investor melakukan investasi (Widoatmodjo, 2012). Investasi didefinisikan sebagai komitmen untuk mengalokasikan sumber daya dengan harapan memperoleh imbal hasil di masa depan (Tandelilin, 2016). Investasi bisa dibagi menjadi dua kelompok besar yaitu investasi pada sektor riil (emas, perak atau properti) dan investasi keuangan. Investasi keuangan dilakukan pada instrumen sekuritas dan valuta asing (Widoatmodjo, 2012). Investor bisa membeli dan menjual sekuritasnya di pasar modal, yang merupakan tempat bertemunya antara penjual dengan pembeli sekuritas (Tandelilin, 2016).

Sekuritas merupakan dokumen yang menunjukkan kepemilikan investor atas perusahaan sehingga berhak mendapatkan keuntungan perusahaan secara proporsional sesuai dengan persentase kepemilikan sekuritas (Darmadji dan Fakhruddin, 2015). Saham adalah salah satu instrumen investasi di pasar modal yang paling banyak diperjualbelikan. Saham didefinisikan sebagai dokumen yang menunjukkan tanda bukti kepemilikan atas perusahaan yang menerbitkannya (Widoatmodjo,2012). Jumlah saham yang dimiliki menunjukkan persentase kepemilikan atas perusahaan tersebut. Saat ini perdagangan saham dilakukan dengan mekanisme perdagangan tanpa warkat (scripless trading) sehingga proses jual beli tidak serta merta memindahkan dokumen fisik sekuritas namun dilakukan secara elektronik untuk selanjutnya dilaksanakan pemindahbukuan (book entry settlement).

Terdapat dua hal yang menimbulkan kesejahteraan bagi investor saham yaitu dividen dan capital gain (Prihadi, 2013). Dividen adalah bagian atau semua keuntungan perusahaan yang di bagikan bagi investor saham sebagai pemilik perusahaan. Faktor utama penentu dividen adalah kemampuan perusahaan dalam menghasilkan laba (Prihadi, 2013). Selain dividen, investor juga mendapatkan keuntungan ketika menjual kembali saham yang dimilikinya, disaat harga sahamnya meningkat.

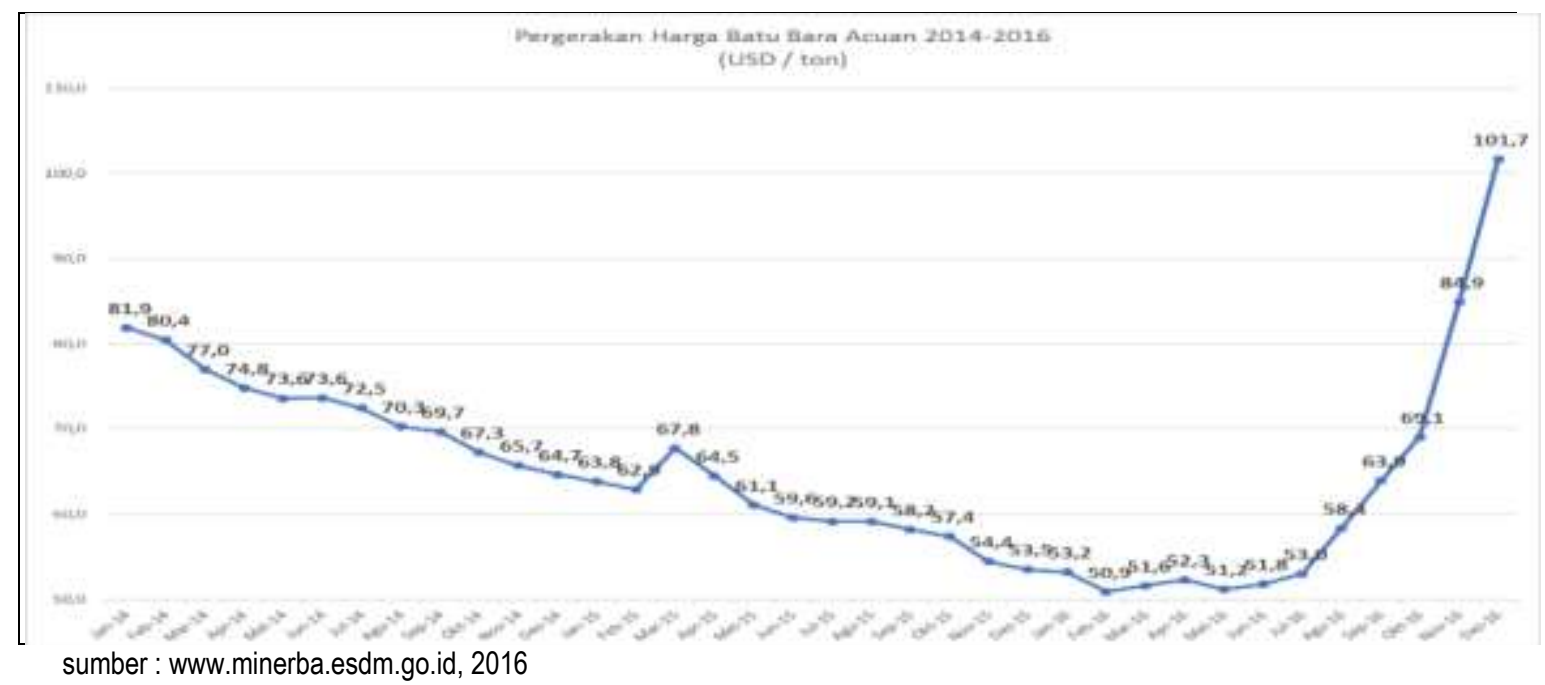

Gambar 1. Pergerakan harga batu bara acuan 2014-2016

Untuk meningkatkan keuntungan dan mengelola risiko dalam memilih saham, investor hendaknya mengetahui sektor saham yang berpotensi mengalami penguatan. Salah satu sektor saham yang cukup potensial adalah saham di sektor pertambangan batu bara. Hal ini dikarenakan 
harga batu bara acuan yang sebelumnya menurun mengalami penguatan kembali (rebound). Harga batu bara acuan (HBA) pada bulan Januari 2014 menurun dari US\$ 81,9 per ton menjadi US\$ 50,9 per ton di bulan Februari 2016. Namun sejak Maret 2016 HBA menguat ke harga US\$ 81,9 per ton dan puncaknya HBA menjadi US\$ 101,7 per ton pada bulan Desember 2016 (Kementerian ESDM, 2016).

Menurut data Badan Pusat Statistik (BPS) pada tahun 2006-2015 terdapat peningkatan ekspor batubara ke negara tujuan utama ekspor batu bara yaitu India,Tiongkok, Korea Selatan dan Jepang.

Tabel 1. Rekapitulasi Ekspor Batu Bara Indonesia 2006-2015

\begin{tabular}{|c|c|c|c|c|c|c|c|c|c|c|}
\hline Negara Tujuan & 2006 & 2007 & 2008 & 2009 & 2010 & 2011 & 2012 & 2013 & 2014 & 2015 \\
\hline & \multicolumn{10}{|c|}{ Berat Bersih: 000 ton } \\
\hline India & 20.742 & 25.179 & 26.328 & 39.109 & 51.254 & 74.723 & 96.076 & 118.289 & 136.352 & 124.482 \\
\hline Tiongkok $^{1)}$ & 6.657 & 14.122 & 15.674 & 39.331 & 74.805 & 104.143 & 115.702 & 130.393 & 99.280 & 72.741 \\
\hline Korea Selatan & 21.314 & 27.372 & 26.287 & 33.418 & 43.276 & 39.598 & 37.899 & 36.273 & 35.632 & 34.016 \\
\hline Jepang & 35.296 & 35.199 & 36.260 & 32.218 & 35.267 & 35.364 & 35.518 & 37.712 & 35.585 & 32.509 \\
\hline Taiwan & 26.724 & 24.863 & 24.669 & 24.723 & 25.002 & 27.132 & 29.105 & 28.323 & 27.272 & 24.393 \\
\hline Thailand & 8.475 & 11.963 & 12.823 & 11.230 & 13.082 & 13.294 & 14.676 & 14.365 & 16.242 & 17.865 \\
\hline Malaysia & 8.783 & 9.377 & 11.104 & 12.483 & 15.536 & 17.338 & 16.138 & 17.129 & 14.494 & 16.568 \\
\hline Pilipina & 5.818 & 6.024 & 6.338 & 7.518 & 11.111 & 10.990 & 11.636 & 14.509 & 15.021 & 15.823 \\
\hline Lain-lain & 50.201 & 41.688 & 41.539 & 34.763 & 29.512 & 30.816 & 27.556 & 27.333 & 28.361 & 28.574 \\
\hline Jumlah & 184.009 & 195.786 & 201.022 & 234.793 & 298.844 & 353.398 & 384.307 & 424.325 & 408.238 & 366.970 \\
\hline
\end{tabular}

Sumber : laporan NPI Bank Indonesia, 2016

Dengan berkembangnya industri batu bara di Indonesia dan penguatan harga batu bara, investasi saham sektor pertambangan batu bara diharapkan dapat menghasilkan return yang menjanjikan. Return diartikan sebagai harapan imbal hasil terhadap investasi yang akan di terima di kemudian hari (Tandelilin, 2016). Oleh karena itu, investor harus mempertimbangkan trade-off antara return dan risiko.

Analisis perusahaan perlu dilakukan investor untuk mencari perusahaan manakah yang dalam industri terpilih yang paling prospektif dengan menganalisis laporan keuangannya. Laporan keuangan adalah laporan mengenai kegiatan operasional perusahaan selama beberapa periode sehingga dapat menjelaskan posisi perusahaan (Brigham dan Houston, 2015). Dengan menganalisis laporan keuangan investor mampu meramalkan masa depan perusahaan. Analisis rasio biasanya digunakan sebagai teknik dasar untuk menganalisis laporan keuangan (Prihadi, 2013). Secara garis besar, investor melakukan analisis rasio atas laporan keuangan yang terdiri dari: (1) likuiditas (2) solvabilitas (3) profitabilitas.

Likuiditas menjelaskan sejauh mana perusahaan mampu memenuhi kewajiban jangka pendek perusahaan (Prihadi, 2013). Aset lancar merupakan aset yang dapat dikonversi menjadi kas pada harga pasar yang berlaku. Current ratio (rasio lancar) biasa digunakan investor yang mengukur sejauh mana aset lancar untuk melunasi utang lancar.

Rasio solvabilitas mengukur kemampuan perusahaan dalam membayar utang (Prihadi, 2013). Perusahan menggunakan utang dengan tujuan sebagai berikut: (1) mengurangi kewajiban pajak karena penggunaan utang pada akhirnya menyisakan laba bersih. Investor bisa mendapatkan dividen lebih besar bila laba bersihnya meningkat (2) perusahaan dapat memanfaatkan utang perusahaan untuk mengakusisi aset, melunasi beban bunga utang dan bisa memberikan dividen jika persentase laba operasi terhadap aset melebihi tingkat bunga atas utang (Brigham dan Houston, 
2015). Salah satu alat ukur solvabilitas adalah DER (debt to equity ratio) yang membandingkan antara total utang yang dimiliki perusahaan dengan total aset perusahaan (Brigham and Houston, 2015). Rasio profitabilitas adalah kemampuan menghasilkan laba, yang merupakan tolak ukur keberhasilan perusahaan (Prihadi, 2013). Investor akan lebih berkepentingan terhadap rasio profitabilitas. Salah satu rasio profitabilitas yang digunakan investor adalah ROA (return on assets) yang membandingkan laba bersih dengan total aset. Artikel ini bertujuan untuk menganalisis pengaruh faktor-faktor fundamental CR (current ratio), MP/TA (mining properties to total assets ratio), FA/TA (fixed assets to total assets ratio), DER (debt to equity ratio) dan ROA (return on assets) terhadap return saham perusahaan pertambangan batu bara yang terdaftar di BEl.

\section{Analisis Fundamental}

Untuk mendapatkan return yang optimal dan meminimalkan risiko, investor dapat melakukan analisis fundamental untuk menilai masa depan perusahaan (Tandelilin, 2016). Esensi dari analisis fundamental adalah untuk memprediksi pendapatan dan dividen yang diharapkan dari sebuah perusahaan untuk menentukan harga saham yang wajar (Bodie et al, 2016).

Analisa fundamental dilakukan dengan menganalisis laporan keuangan yang menggambarkan posisi perusahaan dan kegiatan operasionalnya pada periode tahun berjalan dan beberapa periode sebelumnya (Brigham dan Houston, 2015). Laporan keuangan memberikan dasar bagi evaluasi prestasi yang dicapai perusahaandan dengan mempertimbangkan aspek bisnis dan ekonomi lain, untuk meramalkan masa depan perusahaan (Weaver dan Lehigh, 2001). Pada dasarnya keberhasilan kinerja perusahaan menentukan dividen yang dibayarkan pada pemegang saham serta meningkatkan harga saham di pasar modal. Sehingga dapat disimpulkan bahwa inti dari analisis laporan keuangan adalah mengetahui masa depan perusahaan (Brigham dan Houston, 2015).

Terdapat tiga jenis laporan keuangan yang dibuat oleh perusahaan (Prihadi, 2013) yaitu:

a. Neraca yang terdiri dari aset, utang dan modal pada satu periode berjalan dan periode sebelumnya. Neraca menjelaskan mengenai posisi keuangan perusahaan.

b. Laporan laba rugi dapat menjelaskan mengenai prestasi yang diperoleh perusahaan yang diindikasikan dari laba. Laba terbentuk dari selisih antara pendapatan dengan biaya di periode yang sama.

c. Laporan arus kas adalah pergerakan kas perusahaan yang menggambarkan bagaimana perusahaan memperoleh dan menggunakan kas.

Teknik dasar yang dikembangkan dalam analisis laporan keuangan adalah analisis rasio yaitu dengan melakukan perbandingan antar akun dilaporan keuangan di periode yang sama (Prihadi, 2013). Manfaat yang diperoleh dari analisis rasio adalah menghindari kesalahan pada angka mutlak di laporan keuangan karena analisis ini membandingkan angka secara relatif. Secara umum analisis rasio laporan keuangan adalah sebagai berikut:

\section{Rasio Likuiditas (Liquidity Ratio)}

Likuiditas mengukur seberapa besar aset lancar perusahaan untuk melunasi utang perusahaan yang berumur di bawah satu tahun (Prihadi, 2013). Salah satu rasio untuk mengukur rasio likuiditas adalah $\mathrm{CR}$ (current ratio). Secara rumus $\mathrm{CR}$ diperoleh sebagai berikut: 


$$
\text { Current Ratio }=\frac{\text { Current Assets }}{\text { Current Liability }}
$$

Aset lancar (current assets) adalah aset yang terdiri dari kas, sekuritas yang dapat dijual kembali, piutang usaha dan persediaan dan semua aset yang dapat di cairkan kurang dari satu tahun. Sedangkan kewajiban lancar (current liability) adalah kewajiban perusahaan yang harus dilunasi kurang dari satu tahun, yang terdiri dari utang usaha, pajak dan semua kewajiban perusahaan lainnya yang harus dilunasi kurang dari satu tahun (Brigham dan Houston, 2015).

Jika CR perusahaan menurun maka mengindikasikan kewajiban jangka pendek perusahaan naik lebih cepat daripada aset lancar dan merupakan indikasi adanya masalah (Brigham dan Houston, 2015). Sehingga dapat disimpulkan bahwa bila CR meningkat maka akan membuat permintaan terhadap saham ini meningkat karena peningkatan CR dianggap sebagai sinyal positif oleh investor. Sebagai akibat dari tingkat permintaan yang melebihi tingkat penawaran, menyebabkan harga saham mengalami peningkatan. Apabila di akhir periode, harga saham lebih tinggi dibandingkan ketika di awal periode, hal ini akan menyebabkan peningkatan return saham.

\section{Rasio Pengelolaan Utang atau Solvabilitas}

Rasio pengelolaan utang atau solvabilitas perusahaan berhubungan dengan kemampuan membayar utang, tidak terbatas utang jangka pendek namun juga jangka panjang (Prihadi, 2013). DER (debt to equity ratio) digunakan sebagai alat ukur solvabilitas karena membandingkan total utang yang dimiliki perusahaan dibandingkan dengan total modal sendiri. Secara rumus DER diperoleh sebagai berikut:

$$
\text { Debt to Equity }=\frac{\text { Total Debt }}{\text { Total Equity }}
$$

Terdapat dua alasan dibalik penggunaan utang yaitu (1) kewajiban pajak akan berkurang karena penggunaan utang sehingga keuntungan perusahaan lebih besar yang pada akhirnya berpotensi untuk membagikan dividen lebih besar (2) utang bisa di gunakan untuk membeli dan mengakuisisi aset dan membayar bunga atas utang sehingga perusahaan lebih berkembang (Brigham dan Houston, 2015).

Menurut trade-off teory perusahaan akan menggunakan utang sampai pada tingkat hutang tertentu, dimana penghematan pajak dari tambahan hutang sama dengan biaya kesulitan keuangan (financial distress) yaitu biaya yang meningkat akibat dari turunnya kredibilitas suatu perusahaan.

Dengan demikian maka DER yang meningkat pada batas tertentu akan memberikan sinyal positif bagi investor, sehingga permintaan terhadap saham tersebut meningkat. Sebagai akibat dari tingkat permintaan yang melebihi tingkat penawaran, menyebabkan harga saham meningkat. Apabila di akhir periode, harga saham lebih tinggi dibandingkan ketika di awal periode akan menyebabkan peningkatan return saham.

\section{Rasio Profitabilitas}

Profitabilitas adalah rasio keuangan laporan keuangan perusahaan yang merefleksikan kemampuan perusahaan untuk memperoleh keuntungan (Prihadi, 2013). ROA (return on aset) biasa digunakan investor untuk mengukur profitabilitas perusahaan. ROA dapat diartikan sebagai hasil total dari aktivitas perusahaan dalam mendayagunakan aset perusahaan dan mengukur hasil total untuk 
kreditor dan investor, sebagai penyedia dana (Prihadi, 2013). Secara rumus ROA diperoleh sebagai berikut:

$$
R O A=\frac{\text { Net Income }}{\text { Total Assets }}
$$

ROA yang meningkat akan memberikan sinyal positif bagi investor, sehingga permintaan terhadap saham tersebut meningkat. Sebagai akibat dari tingkat permintaan yang melebihi tingkat penawaran akan menyebabkan harga saham meningkat. Apabila di akhir periode, harga saham lebih tinggi dibandingkan ketika di awal periode akan menyebabkan peningkatan return saham.

\section{Tahap Kegiatan Operasi Pertambangan}

Industri pertambangan memiliki karakteristik tertentu yang tidak dimiliki industri yang lain, yaitu padat modal dan membutuhkan investasi jangka panjang. Selain itu, bahan galian terletak di wilayah-wilayah terpencil sehingga memiliki infrastruktur yang terbatas. Hal tersebut membuat industri pertambangan sangat berisiko tinggi baik dari segi aspek teknis dan finansial. Secara umum industri pertambangan berbentuk usaha terpadu dimana melakukan empat tahap kegiatan sebagai berikut:

\section{a. Eksplorasi}

Eksplorasi adalah kegiatan di wilayah tambang untuk menemukan dan melakukan evaluasi terhadap taksiran cadangan bahan galian tambang yang secara teknis dan ekonomis memungkinkan untuk diproduksi di masa depan. Namun kegiatan eksplorasi tidak menjamin akan dilanjutkan ke tahap selanjutnya bila cadangan bahan galian yang ditemukan tidak layak secara komersial.

Urutan kegiatan eksplorasi adalah: (1) penyelidikan umum (2) administrasi dan perijinan (3) geofisika dan geologi (4) pemboran eksplorasi (5) evaluasi. Di dalam laporan laba-rugi laporan keuangan perusahaan, biaya eksplorasi di catat sebagai beban eksplorasi.

\section{b. Pengembangan dan Konstruksi}

Setelah taksiran cadangan bahan galian tambang ditemukan tahap selanjutnya adalah tahap pengembangan yaitu kegiatan untuk mempersiapkan cadangan terbukti sampai bisa diproduksi secara komersial. Biaya ditahap pengembangan ditangguhkan pembebanannya.

Ketika produksi batu bara dimulai maka biaya yang ditangguhkan tersebut seperti akumulasi biaya pengembangan dan biaya eksplorasi tersebut dijumlahkan dan diamortisasi. Langkah selanjutnya setelah tahap pengembangan adalah tahap konstruksi yaitu kegiatan membangun sarana dan prasarana untuk mendukung kegiatan produksi. Semua biaya tersebut dikapitalisasi sebagai aset tetap (fixed assets) dan selanjutnya di depresiasi menyesuaikan dengan umur ekonomis dari aset yang bersangkutan.

Ketika perusahaan telah mengambil keputusan pengembangan, maka jumlah aset eksplorasi dan evaluasi yang tercatat sebelumnya di tahap eksplorasi dipindahkan sebagai akun properti pertambangan (mining properties). Pengakuan aset pertambangan diakui sebesar nilai wajarnya. Dalam menganalisis fundamental perusahaan batu bara investor dapat menganalisis MP/TA (mining properties to total assets) yang membandingkan properti pertambangan terhadap total aset. Secara rumus MP/TA diperoleh sebagai berikut:

$$
\text { MP/TA }=\frac{\text { Mining Properties }}{\text { Total Assets }}
$$


Investor cenderung berinvestasi pada perusahaan yang memiliki MP/TA yang besar karena menunjukkan banyaknya cadangan terbukti untuk bisa di produksi secara komersial di masa depan. MP/TA yang tinggi akan memberikan sinyal positif terhadap investor yang pada akhirnya meningkatkan permintaan terhadap saham tersebut. Sebagai akibat dari tingkat permintaan yang melebihi tingkat penawaran, akan menyebabkan harga saham meningkat. Apabila di akhir periode, harga saham lebih tinggi dibandingkan ketika di awal periode akan menyebabkan peningkatan return saham.

\section{c. Produksi}

Tahap produksi adalah kelanjutan dari tahap pengembangan dan konstruksi dimana di kegiatan ini dimulai dari pengangkatan bahan galian untuk selanjutnya diolah lebih lanjut dan dipasarkan. Kegiatan produksi dilakukan dengan tahapan kegiatan sebagai berikut:

a) Stripping yaitu kegiatan menggaru, menggaliserta mentransportasikan tanah ke lokasi penimbunan yang berasal dari lokasi penggalian bahan tambang.

b) Pengiriman bahan galian ke permukaan bumi yang dilakukan dengan peledakan dan penggunaan alat-alat berat (bulldozer dan shovel).

c) Pemurnian untuk memisahkan bahan galian dengan bahan galian ikutan lainnya. Selanjutnya adalah kegiatan pencucian bahan tambang dengan menggunakan air, bahan kimia atau saringan.

d) Kegiatan pengangkutan bahan galian dilakukan dengan menggunakan peralatan dari lokasi penambangan ke stasiun pengumpul.

\section{d. Pengelolaan Lingkungan Hidup}

Selain memiliki risiko teknis dan ekonomis, kegiatan penambangan batu bara bisa menimbulkan polusi di lingkungan tambang dan perusakan lingkungan. Sebagai bentuk tanggung jawab, perusahaan perlu mengalokasikan biaya pengelolaan lingkungan hidup agar dampak negatif dari kegiatan pertambangan bisa dikendalikan. Biaya yang termasuk dalam kegiatan ini adalah biaya pengadaan sarana dan prasarana pengelolaan lingkungan hidup. Di dalam laporan keuangan biaya ini dicatat sebagai aset tetap (fixed assets) dan di depresiasi.

Sehingga bisa di simpulkan bahwa aset tetap (fixed assets) adalah kapitalisasi dari sarana dan prasarana yang dibangun di tahap konstruksi dan di tahap pengelolaan lingkungan hidup dan disusutkan menurut umur ekonomisnya. Dalam menganalisis fundamental perusahaan batu bara investor dapat menganalisis FA/TA (fixed assets to total assets) yang membandingkan aset tetap terhadap total aset. Secara rumus FA/TA diperoleh sebagai berikut:

$$
\text { FA/TA }=\frac{\text { Mining Properties }}{\text { Total Assets }}
$$

Investor cenderung memilih perusahaan yang memiliki FA/TA yang besar, karena menunjukkan besarnya kekayaan perusahaan. Bila investor mendapatkan informasi mengenai perusahaan yang memiliki FA/TA yang tinggi, hal ini menyebabkan permintaan terhadap saham tersebut meningkat. Sebagai akibat dari tingkat permintaan yang melebihi tingkat penawaran akan menyebabkan harga saham meningkat. Apabila di akhir periode harga saham lebih tinggi di bandingkan ketika di awal periode, akan menyebabkan peningkatan return saham.

\section{Kerangka Pemikiran Teoritis}

Hipotesis dapat diartikan sebagai adalah jawaban sementara yang kebenaranya harus diuji (Gunawan, 2016). Adapun perumusan hipotesis di dalam penelitian ini adalah: 


\section{Kerangka TeoritisCR dengan Return Saham}

CR adalah indikator yang menggambarkan besarnya aset lancar perusahaan untuk melunasi utang lancar. CR yang tinggi menunjukan kemampuan perusahaan yang tinggi dalam menjalankan kegiatan operasional perusahaan sehari hari. Investor lebih menyukai CR yang tinggi karena menunjukan tingginya likuiditas perusahaan. Menurut teori EMH investor akan aktif dalam menganalisis semua informasi yang tersedia di pasar dan akan mengambil keputusan menyesuaikan informasi yang ada. Bila terdapat informasi bahwa CR suatu perusahaan meningkat, maka akan meningkatkan permintaan terhadap saham tersebut. Bila permintaan terhadap saham melebihi penawarannya maka akan membuat harga saham meningkat. Apabila di akhir periode harga saham di lebih tinggi dibandingkan dengan di awal periode, maka return saham akan meningkat.

Hipotesis penelitian ini adalah CR memberikan pengaruh positif terhadap return saham, dimana peningkatan nilai CR akan meningkatkan return sahamnya. Hasil penelitian Soepardi (2015) menguatkan hipotesis ini bahwa CR mempunyai pengaruh terhadap return saham.

\section{Kerangka Teoritis MP/TA dengan Return Saham}

Properti pertambangan (mining properties) adalah aset eksplorasi dan evaluasi yang sebelumnya tercatat di laporan keuangan sebagai beban eksplorasi dan evaluasi dan dipindahkan menjadi akun properti pertambangan ketika perusahaan telah mengambil keputusan pengembangan. Properti pertambangan menunjukkan besarnya cadangan terbukti masih banyak untuk bisa di produksi secara ekonomis di masa depan.

Semakin besar MP/TA, semakin menunjukan tingginya cadangan terbukti bahan galian batu bara yang bisa di tambang secara komersial dibandingkan dengan total aset. Menurut teori EMH harga saham mencerminkan informasi yang tersedia (available information). Sehingga bila investor mendapatkan informasi mengenai perusahaan yang memiliki MP/TA yang tinggi akan menyebabkan peningkatan permintaan terhadap saham perusahaan tersebut. Bila peningkatan permintaan melebihi penawaran saham maka akan membuat harga saham meningkat. Apabila di akhir periode harga saham di lebih tinggi dibandingkan dengan di awal periode, maka return saham akan meningkat. Hipotesis penelitian ini adalah MP/TA memberikan pengaruh positif terhadap return saham, dimana peningkatan MP/TA akan meningkatkan return saham.

\section{Kerangka Teoritis FA/TA dengan Return Saham}

Aset tetap (fixed assets) adalah kapitalisasi dari sarana dan prasarana yang dibangun di tahap konstruksi dan di tahap pengelolaan lingkungan hidup dan selanjutnya disusutkan menurut umur ekonomisnya. Semakin tinggi FA/TA, menunjukan semakin tinggi aset tetap perusahaan di bandingkan dengan total asetnya. Hal ini merupakan sinyal positif bagi investor.

Menurut teori EMH investor akan bereaksi bila mendapatkan informasi yang mengindikasikan sinyal positif terhadap perusahaan tersebut. Bila investor mendapatkan informasi mengenai perusahaan yang memiliki FA/TA yang tinggi akan menyebabkan permintaan terhadap saham ini meningkat. Permintaan saham yang melebihi penawarannya akan menyebabkan peningkatan harga saham. Apabila di akhir periode harga saham di lebih tinggi dibandingkan dengan di awal periode, maka return saham akan meningkat. Hipotesis penelitian ini adalah FA/TA memberikan pengaruh positif terhadap return saham, dimana peningkatan nilai FA/TA akan meningkatkan return sahamnya. 


\section{Kerangka Teoritis DER dengan Return Saham}

Menurut trade-off teory perusahaan akan menggunakan utang sampai pada tingkat tertentu, dimana penghematan pajak dari tambahan hutang sama dengan biaya kesulitan keuangan. Pada batas tertentu utang memberikan manfaat kepada perusahaan yaitu: (1) kewajiban pajak akan berkurang karena penggunaan utang sehingga pada akhirnya meningkatkan laba bersih dibandingkan dengan tanpa utang. Investor cenderung menyukai perusahaan yang memiliki laba bersih yang besar karena pada akhirnya akan memberikan dividen yang besar (2) Utang dapat di gunakan perusahaan untuk mengakuisisi aset dan melunasi beban hutang (Brigham dan Houston, 2015)

Menurut teori EMH investor akan bereaksi bila mendapatkan informasi yang mengindikasikan sinyal positif terhadap perusahaan tersebut. Sehingga bila investor mendapatkan informasi mengenai peningkatan DER pada tingkat tertentu akan memberikan sinyal positif bagi investor, yang membuat permintaan terhadap saham ini meningkat. Bila peningkatan permintaan saham melebihi penawarannya maka akan membuat harga saham meningkat. Apabila di akhir periode harga saham di lebih tinggi dibandingkan dengan di awal periode, maka return saham akan meningkat. Hal ini sejalan dengan teori EMH bahwa harga saham merupakan cerminan dari informasi yang ada. Hipotesis penelitian ini adalah DER memberikan pengaruh positif terhadap return saham, dimana peningkatan nilai DER pada batas tertentu akan meningkatkan return sahamnya.

\section{Kerangka Teoritis ROA dengan Return Saham}

ROA membandingkan antara laba bersih perusahaan terhadap total aset di periode berjalan. ROA menunjukkan efektivitas perusahaan dalam memanfaatkan asetnya. Semakin tinggi ROA menunjukan semakin tinggi efektifitas perusahaan dalam memanfaatkan asetnya untuk memperoleh laba.

Menurut teori EMH investor akan mengambil tindakan bila mendapatkan informasi yang mengindikasikan sinyal positif terhadap perusahaan tersebut. Peningkatan ROA perusahaan adalah sinyal positif yang akan membuat harga saham tersebut meningkat yang diakibatkan oleh meningkatnya permintaan terhadap saham tersebut melebihi penawarannya. Apabila di akhir periode harga saham di lebih tinggi dibandingkan dengan di awal periode, maka return saham akan meningkat.

Hipotesis penelitian ini adalah ROA memberikan pengaruh positif terhadap return saham, dimana peningkatan nilai ROA akan meningkatkan return sahamnya.

\section{METODE PENELITIAN}

Di dalam penelitian ini rasio laporan keuangan perusahaan pertambangan batu bara digunakan sebagai data penelitian. Adapun CR, MP/TA, FA/TA, DER dan ROA digunakan sebagai variabel independen. Sedangkan return saham yaitu selisih harga penutupan saham antara periode $t$ dengan periode $t-1$ digunakan sebagai variabel dependen. Populasi adalah semua sumber informasi yang dijadikan subyek atau obyek penelitian (Wiyono dalam Gunawan, 2016). Sedangkan bagian dari populasi yang mempunyai ciri tertentu sampel merupakan definisi dari sampel (Sugiyono dalam Gunawan, 2016). Penelitian ini menggunakan sampel sebagai berikut:

1. Perusahaan pertambangan batu bara yang terdaftar di Bursa Efek Indonesia.

2. Perusahaan tersebut menyajikan laporan keuangan secara periodik dengan tahun pengamatan 2014-2016. 
3. Di dalam laporan keuangan yang disajikan tersebut terdapat akun properti pertambangan dan aset tetap

\section{Analisis Regresi Linier Berganda}

Analisis yang menyajikan data yang informatif sehingga mudah dipahami oleh yang membacanya adalah definisi dari analisis deskriptif. Analisis ini menjelaskan mengenai karakteristik data seperti: Nilai rata-rata, standar deviasi, nilai minimum dan nilai maksimum. Hubungan antar variabel dependen yang nilainya diduga dipengaruhi oleh beberapa variabel bebas dapat dijelaskan menggunakan metode statistik yaitu analisis regresi berganda (Asra et al, 2017). Analisa regresi berganda digunakan untuk memastikan apakah variabel independen mempengaruhi variabel dependen, dan besaran kontribusi semua variabel bebas untuk menjelaskan keragaman variabel tak bebas tersebut. Secara umum model regresi linier berganda dapat dirumuskan secara matematis sebagai berikut:

Keterangan:

$$
Y_{i}=\beta_{0}+\beta_{1} X_{i 1}+\beta_{2} X_{i 2}+\ldots+\beta_{j} X_{i j}+\varepsilon_{i}
$$

$Y_{i}=$ Pengamatan ke $\mathrm{i}$ dari variabel terikat $Y$

$X_{i j}=$ Pengamatan ke $\mathrm{i}$ dari variabel bebas $\mathrm{j}$ (nilai variabel $\mathrm{Xj}$ dianggap sebagai nilai tetap yang diketahui (known constant)

$\varepsilon i=$ suku random (suku galat) dari pengamatan ke $\mathrm{i}$

$\beta \mathrm{j}=$ koefisien regresi dari variabel $\mathrm{Xj}$ disebut juga dengan parameter regresi

$\mathrm{i} \quad=1,2,3, \ldots \mathrm{n}$; dengan $\mathrm{n}=$ banyaknya pengamatan

$\mathrm{j} \quad=0,1,2,3, \ldots \mathrm{n}$; dengan $\mathrm{n}=$ banyaknya variabel independent

Untuk membuktikan hipotesis di atas maka dilakukan analisis regresi linier berganda, maka perlu ditentukan kekuatan hubungan variabel bebas terhadap variabel tidak bebas. Adapun persamaannya adalah sebagai berikut:

$$
P=\beta_{0}+\beta_{1} C R+B_{2} M P / T A+\beta_{3} F A / T A+\beta_{4} D E R+\beta_{5} R O A+\varepsilon
$$

Keterangan:

$\begin{array}{ll}\mathrm{P} & =\text { return saham } \\ \beta_{0} & =\text { konstanta } \\ \beta_{1}, \beta_{2}, \beta_{3}, \beta_{4}, \beta_{5} & =\text { koefisien regresi } \\ \mathrm{CR} & =\text { current rasio } \\ \mathrm{FA} / \mathrm{TA} & =\text { fixed aset per total aset ratio } \\ \mathrm{MP} / \mathrm{TA} & =\text { mining properties per total aset ratio } \\ \mathrm{DER} & =\text { debt equity ratio } \\ \mathrm{ROA} & =\text { return on assets } \\ \mathrm{Ei} & =\text { variabel penganggu }\end{array}$

\section{HASIL DAN PEMBAHASAN}

Syarat hipotesis diterima di dalam pengujian regresi berganda adalah berdasarkan nilai thitung dan nilai signifikansi hasil output SPSS. Berdasarkan nilai signifikansi dapat di analisa bahwa apabila signifikansinya lebih kecil dari $0,05($ sig $<0,05)$ maka variabel bebas berpengaruh terhadap variabel terikat, sebaliknya jika signifikansinya lebih besar dari 0,05 (sig $>0,05)$, maka variabel bebas tidak berpengaruh terhadap variabel terikat. 
Tabel 2. Hasil Pengujian Regresi Berganda Data Variabel Penelitian

\begin{tabular}{lcccc}
\hline Variabel & 2014 & 2015 & 2016 & $2014-2016$ \\
\hline CR & 0,33 & 0,37 & 0,40 & 0,31 \\
MP/TA & 0,14 & 0,14 & 0,25 & 0,38 \\
FA/TA & 0,28 & 0,48 & 0,47 & 0,05 \\
DER & 0,29 & 0,02 & 0,01 & 0,44 \\
ROA & 0,09 & 0,14 & 0,06 & 0,05 \\
\hline
\end{tabular}

Note: two significant at 0,05 confidence level

Sumber : SPSS, data diolah.

\section{Pengaruh CR (Current Ratio) Terhadap Return Saham}

Nilai signifikansi CR untuk data periode tahun 2014, 2015, 2016 dan 2014-2016 masingmasing sebesar 0,33, 0,37, 0,40 dan 0,31 lebih besar dari 0,05 (sig > 0,05) maka dapat disimpulkan bahwa variabel $C R$ tidak berpengaruh terhadap return saham. $C R$ mengindikasikan jumlah aset lancar yang dimiliki perusahaan untuk memenuhi utang lancar perusahaan. Bila perusahaan memiliki CR kurang dari 100\% (CR <1 00\%) mengindikasikan bahwa kewajiban perusahaan lebih besar dibandingkan dengan aset lancar yang dimiliki perusahaan. Hal ini akan menyebabkan perusahaan mengalami kesulitan dalam menjalankan kegiatan operasional sehari-hari. Sebaliknya bila perusahaan memiliki CR lebih dari 100\% (CR > 100\%) mengindikasikan bahwa perusahaan disebut dalam keadaan likuid. Hal ini dikarenakan aset lancar yang dimiliki melebihi kewajiban jangka pendeknya, sehingga dapat melunasi utang lancar ketika jatuh tempo.

Namun tingginya nilai CR perusahaan tidak menjaminan dapat memenuhi kewajiban jangka pendek perusahaan tepat waktu bila persentase dari aset lancar tersebut adalah saldo piutang yang besar atau terdapat persediaan (inventori) yang tinggi dan tidak bisa di jual dalam waktu dekat. CR yang tinggi juga dapat diartikan banyak dana segar menganggur dan tidak dioptimalkan untuk menghasilkan laba lebih bersih. Oleh karena CR bisa diartikan positif maupun negatif oleh investor, hal ini membuat CR tidak dijadikan patokan untuk berinvestasi pada saham tersebut. Sehingga dapat disimpulkan bahwa hasil penelitian ini adalah $C R$ tidak berpengaruh terhadap return saham.

Hasil penelitian ini sejalan dengan hasil penelitian dari Hutahuruk, et al (2014), Petcharabul dan Romprasert (2014), Absari, et al (2013) yang menyatakan bahwa CR tidak memiliki pengaruh terhadap return saham. Namun hasil penelitian ini bertentangan dengan hasil penelitian Soepardi (2015) yang menyatakan bahwa CR berpengaruh terhadap return saham.

\section{Pengaruh MP/TA (Mining Properties To Total Assets Ratio) Terhadap Return Saham}

Nilai signifikansi untuk variabel MP/TA pada tahun 2014, 2015, 2016 dan 2014-2016 masingmasing sebesar $0,14,0,14,0,25$ dan 0,38 . Dikarenakan nilai signifikansi untuk semua periode lebih besar dari 0,05 (sig > 0,05) maka dapat disimpulkan bahwa variabel rasio MP/TA tidak berpengaruh terhadap return saham. Properti pertambangan (mining properties) memiliki karakeristik yang berbeda dengan aset komersial lainnya. Properti pertambangan memiliki keterbatasan produksi sesuai dengan jumlah cadangan terbukti. Untuk melakukan produksi terhadap cadangan terbukti bahan galian sangat tergantung pada cuaca dan iklim. Setelah melakukan proses penambangan selanjutnya bahan galian dilakukan proses pemurnian.

Hasil penelitian ini menunjukan bahwa MP/TA yaitu rasio properti pertambangan terhadap total aset tidak berpengaruh terhadap harga saham. Investor memandang bahwa properti pertambangan tidak bisa dijadikan tolak ukur dalam membuat keputusan investasi, karena nilai 
properti pertambangan dihitung dari harga batu bara dan biaya pada saat dilakukan perkiraan cadangan terbukti. Sementara harga batu bara sangat fluktuatif tergantung dari tinggi atau rendahnya permintaan dari negara importir batubara. Musim hujan di daerah pertambangan batu bara dapat menyebabkan produksi batu bara menurun, sehingga walaupun cadangan terbukti batu bara besar, tidak serta merta membuat produksi batu bara besar.

\section{Pengaruh FA/TA (Fixed Assets To Total Assets Ratio) Terhadap Return Saham}

Nilai signifikansi FA/TA untuk data periode tahun 2014, 2015, 2016 masing-masing sebesar $0,29,0,48,0,47$. Dikarenakan nilai signifikansi untuk periode tersebut lebih besar dari 0,05 (sig > $0,05)$ maka dapat disimpulkan bahwa variabel FA/TA tidak berpengaruh terhadap return saham. Sedangkan untuk periode data periode tahun 2014-2016 nilai signifikansi adalah 0,05 dikarenakan nilainya sama dengan 0,05 (sig $\leq 0,05)$ dan nilai beta adalah $-5,360$, maka dapat disimpulkan variabel FA/TA berpengaruh namun negatif terhadap return saham. Hal ini berimplikasi bahwa kenaikan nilai FA/TA akan menyebabkan return saham.

Menurut PSAK 33 yang dimaksud dengan aset tetap adalah kapitalisasi dari semua biaya atas pekerjaan konstruksi dan prasarana ditahap pengembangan dan konstruksi dan semua biaya atas pengadaan prasarana ditahap pengelolaan lingkungan hidup. Industri pertambangan batu bara adalah industri yang padat modal, karena memerlukan investasi aset tetap dan peralatan yang memerlukan modal yang besar.

Hasil penelitian pada masing-masing tahun 2014, 2015 dan 2016 menunjukan bahwa FA/TA atau rasio aset tetap terhadap total aset tidak berpengaruh terhadap return saham. Hal ini dikarenakan investor memandang bahwa FA/TA tidak bisa dijadikan sebagai dasar pertimbangan dalam membuat keputusan investasi. Karena aset tetap hanya digunakan untuk kegiatan operasional dan aset tetep tidak diperuntukan untuk dijual. Aset tetap juga diharapkan untuk digunakan dalam periode jangka panjang. Aset tetap yang berwujud selain tanah, mempunyai umur yang terbatas dan pada akhirnya akan kehilangan manfaatnya sehingga harus diganti. Sehingga hal ini membuat FA/TA tidak dijadikan bahan pertimbangan untuk membuat keputusan investasi.

Namun untuk periode tahun 2014-2016 dapat disimpulkan bahwa FA/TA berpengaruh namun negatif terhadap return saham. Hal tersebut dikarenakan perusahaan pertambangan memiliki karakterstik terentu dibandingkan dengan perusahaan lain, yaitu memerlukan modal yang besar untuk membiayai pembangunan dan pemeliharaan aset tetap, sementara aset tetap mempunyai umur yang terbatas dan pada akhirnya akan kehilangan manfaat ekonomisnya. Sehingga hal ini membuat investor menghindari perusahaan pertambangan batu bara yang memiliki FA/TA yang tinggi, sehingga hal ini membuat permintaan terhadap saham ini menurun. Penurunan permintaan terhadap saham akan menyebabkan penurunan harga saham sehingga return sahamnya menurun.

\section{Pengaruh DER (Debt To Equity Ratio) Terhadap Return Saham}

Nilai signifikansi DER untuk data periode tahun 2014, 2015, 2016 dan 2014-2016 masingmasing sebesar $0,29,0,02,0,01,0,44$. Dikarenakan nilai signifikansi untuk semua periode lebih besar dari 0,05 (sig > 0,05) maka dapat disimpulkan bahwa variabel DER tidak berpengaruh terhadap return saham. Namun hal ini berbeda dengan periode tahun 2015 dan 2016 dimana nilai si lebih kecil 0,05 (sig < 0,05) maka dapat disimpulkan bahwa variabel DER berpengaruh terhadap return saham pada tahun 2015 dan 2016. Nilai beta pada tahun 2015 adalah 0,108 sehingga dapat disimpulkan bahwa untuk tahun 2015 pengaruh DER adalah positif searah dengan return saham, dimana peningkatan DER akan menyebabkan peningkatan return saham. Sebaliknya nilai beta pada 
tahun 2016 adalah -0,833 sehingga dapat disimpulkan bahwa untuk tahun 2016 pengaruh DER adalah negatif searah dengan return saham, dimana peningkatan DER akan menyebabkan penurunan return saham.

DER adalah rasio keuangan yang menggambarkan komposisi antara total utang dan total modal yang dimiliki perusahaan dalam membiayai aset perusahaan. DER yang lebih dari 100\% (DER $>100 \%$ ) dapat diartikan bahwa proporsi kewajiban perusahaan melebihi dari total modal sendiri. Sehingga bila perusahaan kesulitan dalam melunasi kewajibanya, dikhawatirkan tidak memiliki aset yang cukup untuk dijadikan sebagai jaminan.

Hal ini sejalan dengan penelitian ini bahwa untuk periode tahun 2016 DER berpengaruh namun negatif searah dengan return saham, dimana peningkatan DER akan menyebabkan penurunan return saham. Hal ini dikarenakan bagi sebagian investor, peningkatan DER merupakan indikator negatif. Penelitian Tran (2015) yang menguatkan hipotesis ini bahwa DER berpengaruh namun negatif terhadap return saham

Namun sebagian investor memandang bahwa untuk berkembang dan melakukan ekspansi, perusahaan memerlukan utang sebagai leverage. Untuk kebutuhan ini perusahaan memerlukan dana dari pihak ketiga, karena perusahaan tidak mampu untuk memenuhinya sendiri. Selain itu terdapat alasan perusahaan menggunakan utang yaitu: (1) kewajiban pajak akan berkurang karena penggunaan utang sehingga meningkatkan keuntungan perusahaaan, yang pada akhirnya berpotensi untuk meningkatkan dividen bagi investor (2) utang dapat digunakan perusahaan untuk membeli dan mengakuisisi aset, sehingga perusahaan lebih berkembang (Brigham dan Houston, 2015).

Dengan demikian bagi investor peningkatan DER adalah sinyal positif yang akan membuat harga saham meningkat karena menyebabkan peningkatan permintaan terhadap saham tersebut. Bila harga saham di akhir periode lebih tinggi dibandingkan harga di awal periode, maka return saham akan meningkat. Hal ini sejalan dengan penelitian ini bahwa untuk periode tahun 2015, DER berpengaruh dan positif searah dengan return saham, dimana peningkatan DER akan menyebabkan penurunan return saham.

Perbedaan pandangan tersebut di atas, menyebabkan investor tidak menjadikan DER sebagai dasar untuk membuat keputusan investasi. Hasil penelitian ini menunjukan pada periode tahun 2014 dan tahun 2014-2016, DER tidak berpengaruh dengan return saham. Hasil penelitian ini sejalan dengan hasil penelitian Soepardi (2015), Hutahuruk, et al (2014), Petcharabul dan Romprasert (2014), Absari, et al (2013) bahwa DER (debt to equity) tidak berpengaruh terhadap return saham.

\section{Pengaruh ROA (return on assets) Terhadap Return Saham}

Nilai signifikansi ROA untuk data periode tahun 2014, 2015, 2016 dan 2014-2016 masingmasing sebesar 0,09, 0,14, 0,06, 0,05. Dikarenakan nilai signifikansi untuk periode tahun 2014, 2015 dan 2016 lebih besar dari 0,05 (sig >0,05) maka dapat disimpulkan bahwa variabel ROA tidak berpengaruh terhadap return saham.

Namun hal ini berbeda dengan periode tahun 2014-2016 dimana nilai signifikansi sebesar 0,049 lebih kecil 0,05 (sig < 0,05) maka dapat disimpulkan bahwa variabel ROA berpengaruh terhadap return saham. Adapun untuk nilai beta untuk variabel ROA pada periode tahun 2014-2016 sebesar 2,862. Sehingga dapat disimpulkan bahwa untuk periode tahun 2014-2016 pengaruh ROA adalah dan positif searah dengan return saham, dimana peningkatan ROA akan menyebabkan peningkatan return saham. 
ROA adalah rasio keuangan yang menunjukan persentase laba bersih yang diperoleh perusahaan sehubungan dengan penggunaan aset perusahaan atau bisa juga di sebut dengan tingkat pengembalian aset. ROA setiap industri berbeda-beda karena memiliki karekateristik tertentu. Industri yang padat modal seperti perusahaan tambang batu bara akan menghasilkan ROA yang rendah, hal ini dikarenakan industri ini tersebut membutuhkan investasi yang tidak sedikit untuk menjalankan bisnisnya. Hal ini berdampak pada ROA pada industri batu bara tidak bisa di bandingkan dengan industri lain yang tidak memerlukan aset sebesar perusahaan batu bara. Oleh karena itu, investor memandang bahwa ROA tidak bisa di jadikan tolak ukur dalam membuat keputusan investasi pada periode tahun 2014, 2015 dan 2016. Hasil penelitian ini sejalan dengan hasil penelitian Hutahuruk, et al (2014) bahwa hasil penelitiannya mengenai rasio profitabilitas tidak berpengaruh terhadap return saham.

Pada periode 2014-2016 investor menjadikan ROA adalah tolak ukur profitabilitas. Investor selaku pemilik perusahaan ingin mengetahui tingkat imbal hasil dari investasi yang ditanam di perusahaan yang dipilih sebelumnya. Hasil penelitian di periode ini menunjukan bahwa ROA positif searah dengan return saham. Di mana investor yang melihat peningkatan ROA pada perusahaan tertentu akan dianggap sebagai sinyal positif untuk berinvestasi di perusahaan tersebut. Hal ini akan mendorong peningkatan permintaan pada saham tersebut yang pada akhirnya membuat peningkatan harga saham. Apabila harga saham lebih tinggi di bandingkan dengan harga saham periode sebelumnya hal ini akan menyebabkan peningkatan return saham. Namun hasil penelitian ini bertentangan dengan hasil penelitian Soepardi (2015), Tran (2015), Petcharabul dan Romprasert (2014) yang menyatakan rasio profitabilitas berpengaruh terhadap return saham

\section{PENUTUP}

Berdasarkan hasil analisis, CR tidak berpengaruh terhadap return saham. Perusahaan dengan CR tinggi mengindikasikan bahwa perusahaan tidak terkendala dalam membiayai kegiatan operasionalnya sehari-hari. Namun hal ini juga bisa diartikan bahwa perusahaan terlalu banyak menyimpan dana menganggur dan tidak efisien dalam mengelola dana perusahaan. MP/TA tidak berpengaruh terhadap harga saham. Properti pertambangan tidak bisa dijadikan tolak ukur dalam membuat keputusan investasi, karena nilai properti pertambangan dihitung dari harga batu bara dan biaya pada saat dilakukan perkiraan cadangan terbukti, sementara harga jual batu bara sangat fluktuatif.

FA/TA berpengaruh namun negatif terhadap return saham karena aset tetap mempunyai umur yang terbatas dan pada akhirnya akan kehilangan manfaatnya sehingga harus diganti. Sementara memerlukan modal yang besar untuk membiayai pembangunan dan pemeliharaan aset tetap. DER bisa diartikan juga sebagai besarnya kewajiban perusahaan kepada kreditor. Sehingga dikhawatirkan perusahaan memiliki risiko kesulitan dalam melunasi kewajibannya, namun sebagian investor memandang bahwa untuk berkembang dan melakukan ekspansi, perusahaan memerlukan utang sebagai leverage. Penggunaan utang bermanfaat karena dapat mengurangi pajak sehingga laba bersih perusahaan menjadi lebih besar. Perbedaan pandangan investor terhadap DER menyebabkan investor tidak menjadikan DER sebagai dasar untuk pengambilan keputusan investasi.

ROA berpengaruh terhadap return saham karena ROA dapat digunakan investor untuk mengetahui tingkat imbal hasil dari investasi yang ditanam di perusahaan yang dipilih sebelumnya. Hasil penelitian di periode ini menunjukan bahwa ROA dan positif searah dengan return saham. Dikarenakan CR tidak mempengaruhi return saham maka disarankan agar investor tidak membuat keputusan investasi berdasarkan tinggi atau rendahnya CR yang dimiliki perusahaan. Bagi emiten 
agar mengelola aset lancar lebih efisien, sehingga tidak terdapat dana menganggur. Begitu pula sebaliknya tidak disarankan bagi perusahaan memiliki CR yang rendah, karena dikhawatirkan menganggu kegiatan operasional perusahaan.

\section{REFERENSI}

Absari, D. U. A., Sudarma, M., \& Chandrarin, G. (2013). Analisis Pengaruh Faktor Fundamental Perusahaan Dan Risiko Sistematis Terhadap Return Saham. El Muhasaba: Jurnal Akuntansi, 3(2).

Asra, et al. (2017). Analisis Multivariabel: Suatu Pengantar. Bogor: Penerbit In Media.

Bank Indonesia. (2016). Laporan Neraca Pembayaran Indonesia: Triwulan IV 2016. Jakarta: Grup Neraca Pembayaran dan Pengembangan Statistik. Departemen Statistik Bank Indonesia.

Bodie, Z., Kane, A., \& Marcus, A. J. (2016). Manajemen Portofolio dan Investasi. Cetakan kedua. Jakarta: Penerbit Salemba.

Brigham, E.F \& Houston, J. F. (2015). Dasar-dasar Manajemen keuangan, cetakan ketujuh. Jakarta: Salemba Empat.

Darmadji, T \& Fakhruddin, H. M. (2015). Pasar Modal di Indonesia: Pendekatan Tanya Jawab. Jakarta: Salemba Empat.

Gunawan, I. (2016). Pengantar Statistika Inferensial. Jakarta: Rajawali Pers.

http://www.idx.co.id/id-id/beranda/informasipasar/daftarefek/saham.aspx , di akses pada hari Minggu, 4 Juni 2017 Pukul 14.26.

Hutauruk, M. R., Mintarti, H. S., \& Paminto, H. A. (2014). Influence of Fundamental Ratio, Market Ratio and Business Performance to The Systematic Risk and Their Impacts to The Return on Shares at The Agricultural Sector Companies at The Indonesia Stock Exchange for The Period of 2010-2013. Academic Research International, 5(5), 149.

Petcharabul, P., \& Romprasert, S. (2014). Technology industry on financial ratios and stock returns. Journal of Business and Economics, 5(5), 739-746.

Prihadi, T. (2013). Analisis Laporan Keuangan Lanjutan : Proyeksi \& Valuasi. Jakarta : Penerbit PPM Soepardi, E. M. (2015). Perbandingan Analisis Fundamental Terhadap Harga Saham Perusahaan Batu bara Dan Perkebunan Di Bursa Efek Indonesia. Magma Jurnal Magister Manajemen, 1(1).

Tandelilin, E. (2016). Manajemen Investasi: Cetakan 7 Edisi 1. Tangerang Selatan: Universitas Terbuka.

Trần, N. G. (2015). The Impact Of Capital Structure And Financial Performance On Stock Returns Of The Firms In Hose. International Journal of Information Research and Review, Vol. 2, Issue, 06, pp. 734-737, June, 2015.

Weaver, S. C. \& Weston, J F. (2001). Finance And Accounting For Nonfinancial Managers. New York: The McGraw-Hills Company. Diterjemahkan oleh: Emil Salim. Jakarta: PT Buana Ilmu Populer.

Widoatmodjo, S. (2012). Cara Sehat Investasi di Pasar Modal: Pengantar menjadi investor Profesional. Edisi Revisi. Jakarta: Penerbit PT Elex Media Komputindo. 